\title{
Effect of Microencapsulation on Survival at Simulated Gastrointestinal Conditions and Heat Treatment of a Non Probiotic Strain, Lactiplantibacillus plantarum 48M, and the Probiotic Strain Limosilactobacillus reuteri DSM 17938
}

\author{
Clorinda Malmo, Irene Giordano and Gianluigi Mauriello *(D)
}

Citation: Malmo, C.; Giordano, I.; Mauriello, G. Effect of

Microencapsulation on Survival at Simulated Gastrointestinal

Conditions and Heat Treatment of a Non Probiotic Strain

Lactiplantibacillus plantarum 48M, and the Probiotic Strain Limosilactobacillus reuteri DSM 17938. Foods 2021, 10 , 217. https://doi.org/10.3390/ foods 10020217

Academic Editors: Fernanda Galgano and Marisa Carmela Caruso Received: 28 December 2020 Accepted: 18 January 2021 Published: 21 January 2021

Publisher's Note: MDPI stays neutral with regard to jurisdictional claims in published maps and institutional affiliations.

Copyright: (C) 2021 by the authors. Licensee MDPI, Basel, Switzerland This article is an open access article distributed under the terms and conditions of the Creative Commons Attribution (CC BY) license (https:// creativecommons.org/licenses/by/ $4.0 /)$
Department of Agricultural Sciences, University of Naples Federico II, Via Università 100, 80055 Naples, Italy; clomal@yahoo.it (C.M.); irene.giordano@unina.it (I.G.)

* Correspondence: giamauri@unina.it

\begin{abstract}
Cells of the probiotic strain Limosilactobacillus reuteri DSM 17938 and of the non-probiotic strain Lactiplantibacillus plantarum 48M were microencapsulated in alginate matrix by emulsion technique. Survival of microorganisms in the microcapsules was tested against gastrointestinal (GI) simulated conditions and heat stress. Results demonstrated that the microencapsulation process improved vitality of Lactiplantibacillus plantarum 48M cells after GI conditions exposure, allowing survival similarly to the probiotic Limosilactobacillus reuteri DSM 17938. Moreover, microencapsulation was able to protect neither Limosilactobacillus reuteri DSM 17938 nor Lactiplantibacillus plantarum 48M cells when exposed to heat treatments. Microencapsulated Limosilactobacillus reuteri DSM 17938 cells were still able to produce reuterin, an antimicrobial agent, as well as free cells.
\end{abstract}

Keywords: emulsion; alginate; reuterin; stress resistance

\section{Introduction}

Nowadays, a new approach to the meaning of food is well accepted by society. In fact, food was recently established as a way to improve health [1-3], leading to the introduction of the concept of functional foods. Functional foods beneficially affect one or more target functions in the body in a way that is relevant to the state of wellbeing and health or the reduction of the risk of a disease [4]. Today, functional food ingredients include probiotics, prebiotics, vitamins and minerals, which are used in dairy products, sports drinks and baby foods [4-6].

The latest revision of probiotic definition was by the International Scientific Association for Probiotics and Prebiotics [7], an update given on 2001 by FAO/WHO [8]. Most probiotics belong to the genera Lactobacillus and Bifidobacterium, and they are required to be able to survive through the upper GI tract and to colonise the gut. As a matter of fact, the genus Lactobacillus has been recently revised and new genera have been proposed [9]. Probiotics possess three mechanisms of promoting human health: (i) providing end-products of anaerobic fermentation of carbohydrates such as organic acids that can be absorbed by the host, influencing human mood, energy level and even cognitive abilities; (ii) successfully competing with pathogens; (iii) stimulating host immune responses by producing specific polysaccharides [10,11]. A low number of living probiotic cells reach the site of action, as demonstrated by high bacterial mortality during the manufacturing process of functional foods and during the passage through the GI tract. Microencapsulation has been proposed as a way to improve cell survival during probiotics incorporation in foods and after ingestion. Accordingly, a recent paper carefully reviewed the microencapsulation of probiotics for food application [12]. Microencapsulation is defined as the technology for packaging solids, liquid or gaseous materials (the so called "core") in an inert shell, in capsules that can release their contents at controlled rates under specific conditions [13]. Microencapsulation 
techniques used to protect probiotic microorganisms include spray drying, spray cooling, fluidised bed coating/air suspension, extrusion, emulsion and coacervation [14,15]. In the emulsion technique, the cell-polymer suspension is added to vegetable oil and the mixture is homogenised to form a water-in-oil emulsion. In some cases, emulsifiers are added to form a better emulsion to lower the surface tension, resulting in smaller spheres. Then, the water-soluble polymer must be insolubilised to start the gelification within the oily phase, and the beads are harvested by sedimentation. The size of the beads is controlled by the speed of agitation and can vary between $25 \mu \mathrm{m}$ and $2 \mathrm{~mm}$ [16]. This technique is easy to scale up, and the costs depend on the type of vegetable oil used [17]. Moreover, by using this technique, microorganisms are not stressed, as happens for example in the microencapsulation by spray drying. Several encapsulation agents have been proposed for the oral delivery of live probiotic bacteria [12]. Among these, alginate has been widely used to microencapsulate these live microorganisms, because it is non-toxic, food-grade, bioavailable, biocompatible and cheap. Alginic acid is a polyuronic acid composed of various proportions of 1-4 linked $\beta$-D-mannuronic and $\alpha$-L-guluronic acids. Upon addition of sodium alginate solution to a calcium solution, interfacial polymerisation is instantaneous, with precipitation of calcium alginate followed by a more gradual gelation of the interior as calcium ions permeate through the alginate system [12].

Limosilactobacillus reuteri is an obligately heterofermentative species resident in the human GI tract [9]. Some strains belonging to $L$. reuteri species have been used as probiotics for over two decades in a variety of functional foods and healthcare products [18]. The probiotic activity of $L$. reuteri species, both in vivo and in vitro, is partly attributed to their ability to produce 3-hydroxypropionaldehyde (3-HPA) [19]. 3-HPA, also called reuterin, is a broad-spectrum antimicrobial agent produced by L. reuteri during the glycerol metabolism [20].

Lactiplantibacillus plantarum is a facultatively heterofermentative species [9] encountered in a variety of environmental niches, including cheese, meat, fish, and plants. It has a proven ability to survive after gastric transit and to colonise the human gut [21].

The aim of this study was to protect a non-probiotic strain, L. plantarum $48 \mathrm{M}$, comparing to a well-known probiotic strain, L. reuteri DSM 17938. Microencapsulation in alginate matrix was performed by emulsion technique to improve bacterial survival during functional food production and digestion. Accordingly, obtained microcapsules were characterised, testing the tolerance of microencapsulated microorganisms to heat stress and GI conditions.

\section{Materials and Methods}

\subsection{Microorganisms and Culture Conditions}

L. reuteri DSM 17938 and L. plantarum 48M were used in microencapsulation experiments. L. reuteri DSM 17938 was isolated from Reuterin ${ }^{\mathrm{TM}}$ (Noos S.r.l.; BioGaia AB, Stockholm, Sweden) and cultured in MRS Broth (Oxoid) at $37^{\circ} \mathrm{C}$, checked for purity and maintained on MRS Agar (Oxoid).

L. plantarum 48M, belonging to microorganisms collection of Department of Agricultural Sciences, Division of Microbiology, University of Naples Federico II, was previously isolated from fruit samples and characterised. It was cultured in MRS Broth at $30^{\circ} \mathrm{C}$.

Escherichia coli 32, Hafnia alvei 53M and Pseudomonas fragi 25P used in reuterin production test, belonging to the cited collection, were previously isolated from fresh meat samples and characterised [22]. They were cultured in Tryptone Soya Broth (TSB, Oxoid) supplemented with $0.5 \%$ Yeast Extract Powder (Oxoid) at $37^{\circ} \mathrm{C}, 30^{\circ} \mathrm{C}$ and $20^{\circ} \mathrm{C}$, respectively.

\subsection{Microorganisms Microencapsulation}

Bacteria cells were microencapsulated in alginate using the method firstly described by Sheu and Marshall [23] and modified by Truelstrup Hansen et al. [24]. Briefly, $100 \mathrm{~mL}$ of bacterial strain culture in the early stationary phase were harvested by centrifugation 
at $6500 \mathrm{rpm}$ for $10 \mathrm{~min}$. The cell pellet was washed once in an equal volume of a sterile quarter-strength Ringer solution (Oxoid) (Ringer) and weighted. The obtained wet cell pellet was suspended in $18 \mathrm{~g}$ of sterile $1 \%$ alginate (Sigma, product $\mathrm{n}$. A2033) solution. The cell suspension was mixed with $100 \mathrm{~g}$ olive oil (Sigma, product $\mathrm{n}$. O1514) containing $0.5 \%$ Tween 80 (Sigma, product $\mathrm{n}$. P8074) by stirring at $300 \mathrm{rpm}$ for $20 \mathrm{~min}$. Calcium ions, necessary for the alginate gelation, were added in two consecutive steps: first, $60 \mathrm{~g}$ olive oil containing $0.5 \%$ Tween 80 and $62.5 \mathrm{mM} \mathrm{CaCl}_{2}$, stirring at $300 \mathrm{rpm}$ for $20 \mathrm{~min}$, and then $40 \mathrm{~mL}$ buffered peptone solution added with $0.05 \mathrm{M} \mathrm{CaCl}_{2}$. Microcapsules were harvested by one-night sedimentation at room temperature and washed once in a double volume of a sterile quarter-strength Ringer.

All experiments described above were performed using freshly prepared microcapsules. All microcapsules samples were routinely kept at $4{ }^{\circ} \mathrm{C}$.

\subsection{Enumeration of Microencapsulated Cells}

Bacteria entrapped in microcapsules were released by pouring microcapsules in phosphate buffer saline (PBS) (0.1 M, pH 7.0) for 10 min followed by gentle shaking. Viable cell counts of microencapsulated microorganisms were performed by serially diluting $1 \mathrm{~mL}$ of microcapsules, dissolved in PBS, in quarter-strength Ringer and plate-counting on MRS Agar. Colonies were counted after $48 \mathrm{~h}$ of incubation at optimal growth temperature in anaerobic conditions.

\subsection{Calculation of Microencapsulation Efficiency}

After one night sedimentation, three phases were separated: upper oily phase, middle water phase, and bottom microcapsules. Microencapsulation efficiency was calculated using the following formula: $N_{t} / N_{0} \times 100$, where $N_{t}$ is cell loads expressed in $\mathrm{CFU} / \mathrm{mL}$ after microencapsulation and $\mathrm{N}_{0}$ represents cell loads expressed in $\mathrm{CFU} / \mathrm{mL}$ in overnight culture.

\subsection{Simulated GI Conditions}

Simulated gastric conditions were performed using phosphate buffer saline (PBS: $137 \mathrm{mM} \mathrm{NaCl}, 2.7 \mathrm{mM} \mathrm{KCl}, 8.1 \mathrm{mM} \mathrm{Na}_{2} \mathrm{HPO}_{4}, 1.76 \mathrm{mM} \mathrm{KH}_{2} \mathrm{PO}_{4}$ ) at pH 2.5.

Simulated intestinal conditions were performed using MRS Broth supplemented with $0.3 \%$ bile (Sigma, product $\mathrm{n}$. B8381) and indicated as MRS/bile.

In detail, $1 \mathrm{~mL}$ of free or microencapsulated cells (sample before exposure) was suspended in $9 \mathrm{~mL}$ of PBS at $\mathrm{pH} 2.5$ or MRS/bile and incubated at optimal growth temperature for the tested strain. Incubation duration was 3 and $4 \mathrm{~h}$ for simulated gastric and intestinal conditions, respectively. Samples were analysed at the start (T0) and end (T3 or T4) of the incubation period. Surviving bacteria were enumerated by serially diluting $1 \mathrm{~mL}$ aliquots of the test materials, pour plating on MRS Agar and incubating at optimal growth temperature for the tested strain, for $48 \mathrm{~h}$ in anaerobic conditions. Three independent experiments were replicated. Residual population at T0 and T3 (gastric condition) or T4 (intestinal condition) was compared with population before the exposure, and $t$-test was performed on the mean values to ascertain significative difference (see Section 2.9).

\subsection{Heat Treatments}

To assess heat tolerance of microencapsulated L. reuteri DSM 17938 and L. plantarum $48 \mathrm{M}$ cells, bacteria survival was tested against four time-temperature combinations: $60^{\circ} \mathrm{C}$ for $3 \mathrm{~min}, 70^{\circ} \mathrm{C}$ for $2 \mathrm{~min}, 80^{\circ} \mathrm{C}$ for $2 \mathrm{~min}, 80^{\circ} \mathrm{C}$ for $5 \mathrm{~min}$. Samples were prepared as follows: free or microencapsulated cells were 10-fold diluted in MRS Broth and sealed in glass capillary tubes $(\varnothing 2 \mathrm{~mm})$. The tubes were then placed in a thermostatic water bath and treated at the conditions cited above. At the end of the period, glass tubes were removed and rapidly cooled under running tap water.

Aliquots were sampled before and after thermal treatments and counted by serially diluting $1 \mathrm{~mL}$ aliquots of the test material, pour plating on MRS Agar and incubating at 
optimal growth temperature for the tested strain for $48 \mathrm{~h}$. Results were expressed in terms of surviving percentage as $\mathrm{N}_{t} / \mathrm{N}_{0} \times 100$, where $\mathrm{N}_{0}$ and $\mathrm{N}_{t}$ are cell loads expressed in $\mathrm{CFU} / \mathrm{mL}$ before and after heat exposure, respectively. Three independent experiments were carried out.

\subsection{Viable Staining of Microencapsulated Bacterial Cells}

Fluorescence microscopy test was used to investigate cell membrane damage after microencapsulation procedure or after exposure of samples to GI conditions and heat treatments. Furthermore, the test showed possible structural changes of microcapsules. Cells were dyed by using LIVE/DEAD ${ }^{\circledR}$ BacLight ${ }^{\text {TM }}$ Bacterial Viability Kit (Molecular Probes, Eugene, Oregon) according to the procedure previously described [25]. Briefly, a stock solution of the two fluorochromes was prepared with $0.7 \mu \mathrm{L}$ of SYTO 9 (green dye) and $1 \mu \mathrm{L}$ of propidium iodide (red dye) in $330 \mu \mathrm{L}$ of sterile deionized water. Microorganisms cultures and microcapsules exposed to GI conditions or heat treatments were ready for dyeing. Freshly prepared microcapsules, instead, were threefold diluted by adding quarterstrength Ringer. Fluorochromes stock solution $(6 \mu \mathrm{L})$ was applied to $10 \mu \mathrm{L}$ of each sample and incubated in the dark for $15 \mathrm{~min}$ at room temperature. After staining, samples were observed using a Nikon Eclipse E400 epifluorescence microscope (Nikon, Tokyo, Japan) equipped with an UV lamp and a $40 \times$ magnification objective. Images were captured by a Nikon Coolpix 4500 Digital Camera equipped with a microscope adapter.

\subsection{Reuterin Production Assay}

Reuterin production from L. reuteri DSM 17938 cells was tested by an antagonistic deferred agar spot test [26]. Ten microlitres of sample (free or microencapsulated cells) were spotted on plates of MRS Agar supplemented with $250 \mathrm{mM}$ glycerol and incubated in anaerobic conditions at $37^{\circ} \mathrm{C}$ for $24 \mathrm{~h}$. Then, plates were covered with $10 \mathrm{~mL}$ of TSB supplemented with $0.75 \%$ agar and $0.5 \%$ yeast extract and seeded with $2 \%$ of an overnight culture of the indicator strain (Escherichia coli 32, Hafnia alvei 53M or Pseudomonas fragi 25P). After the incubation at optimal growth temperature for $24 \mathrm{~h}$, the antimicrobial activity was observed as an inhibition zone of the indicator organism around the sample.

\subsection{Data Analysis}

Analyses were carried out in triplicate, and cell counts were expressed as geometric means of $\log \mathrm{CFU} / \mathrm{mL}$ for 3 independent experiments. Statistical analyses were conducted using two-tailed $t$-tests, and significance was declared at $p \leq 0.05$.

\section{Results and Discussion}

\subsection{Microencapsulation and Encapsulation Efficiency}

Results of microencapsulation experiments for both strains are reported in Table 1. After overnight sedimentation, three different phases were visualised, and an upper oily phase of about $160 \mathrm{~mL}$, a middle water opalescent phase of about $20 \mathrm{~mL}$ and finally a bottom jelly water phase of about $30 \mathrm{~mL}$ appeared, probably containing the microcapsules. In the upper phase, we were able to recover all the oil used during the microencapsulation process; the solutions of water and $\mathrm{CaCl}_{2}$, peptone and alginate were probably distributed in the middle and bottom phase. Then, it could be calculated that during the microencapsulation process, about $10 \mathrm{~mL}$ of water probably remained entrapped in the alginate network. The microscopic observation led to the results reported in Table 1. In particular, in the oily phase, neither free cells nor microcapsules were detected; instead, in the water middle phase, only free undamaged cells were visualised. Finally, the bottom phase appeared mainly constituted by microcapsules containing green cells. 
Table 1. Microencapsulation data of L. reuteri DSM 17938 and L. plantarum 48M. The CFU/mL are adjusted to $100 \mathrm{~mL}$ (see Section 2.4).

\begin{tabular}{|c|c|c|c|c|c|c|c|}
\hline \multirow[b]{2}{*}{ Phases } & \multirow{2}{*}{$\begin{array}{l}\text { Volume of Each } \\
\text { Phase mL }\end{array}$} & \multicolumn{3}{|c|}{ L. reuteri DSM 17938} & \multicolumn{3}{|c|}{ L. plantarum $48 \mathrm{M}$} \\
\hline & & $\begin{array}{l}\text { Fluorescence } \\
\text { Microscopy }\end{array}$ & $\begin{array}{l}\text { Log } \\
\text { CFU/mL }\end{array}$ & $\begin{array}{l}\text { Encapsulation } \\
\text { Efficiency \% }\end{array}$ & $\begin{array}{l}\text { Fluorescence } \\
\text { Microscopy }\end{array}$ & $\begin{array}{l}\text { Log } \\
\text { CFU/mL }\end{array}$ & $\begin{array}{l}\text { Encapsulation } \\
\text { Efficiency \% }\end{array}$ \\
\hline OILY & 160 & $\begin{array}{c}\text { No free cells, } \\
\text { no microcapsules }\end{array}$ & 0 & & $\begin{array}{c}\text { No free cells, } \\
\text { no microcapsules }\end{array}$ & 0 & \\
\hline WATER & 20 & Free Cells & 7.36 & & Free Cells & 4.47 & \\
\hline CAPSULES & 30 & $\begin{array}{l}\text { Microcapsules } \\
\text { with some free } \\
\text { cells }\end{array}$ & 9.04 & 91.53 & $\begin{array}{l}\text { Microcapsules } \\
\text { with some free } \\
\text { cells }\end{array}$ & 7.63 & 65.28 \\
\hline
\end{tabular}

The LIVE/DEAD ${ }^{\circledR}$ Bacterial Viability Kit $\left(\right.$ BacLight $^{\mathrm{TM}}$ ) was used to evaluate the microcapsules and cell conditions after the microcapsules preparation. Briefly, the BacLight ${ }^{\mathrm{TM}}$ was composed of two fluorochromes: the SYTO $9^{\mathrm{TM}}$ and the propidium iodide. The SYTO 9 can penetrate the cell membrane, dyeing the entire cell green, whereas the propidium iodide can only penetrate the damaged cell membrane and, combined with DNA, dyes the cell red when illuminated with UV rays.

The observation of microcapsules by fluorescence microscopy showed generally spherical particles; however, some elliptical-shaped capsules were observed as well. The microcapsule size was not homogeneous, ranging from 40 to $150 \mu \mathrm{m}$ (Figure 1a,b). The cells included in the microcapsules appeared green; therefore, no cell-wall damage occurred during the microcapsule preparation. However, some red cells were also observed, especially for the L. reuteri DSM 17938 (Figure 1a), and a few free cells were detected.

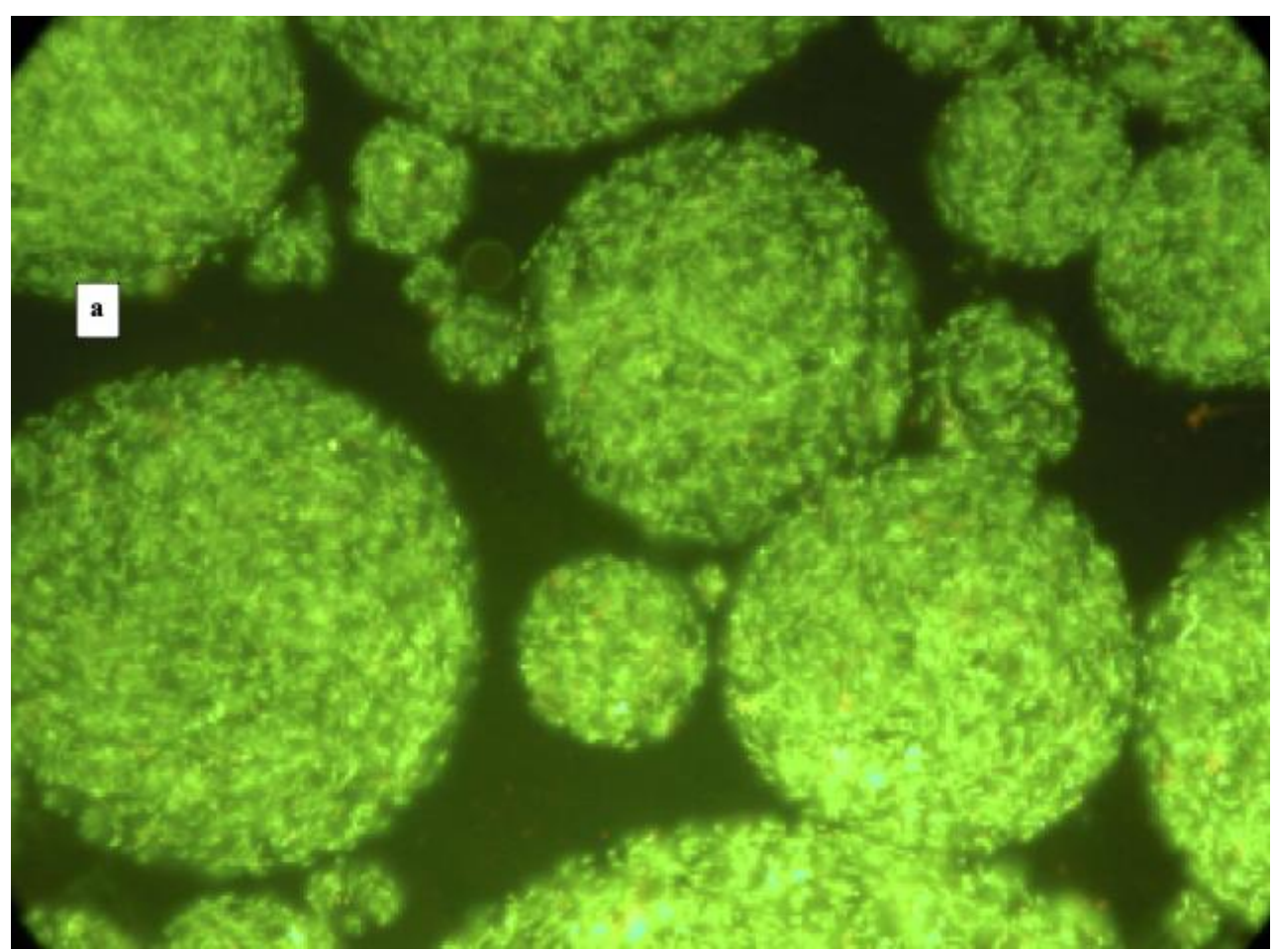

Figure 1. Cont. 


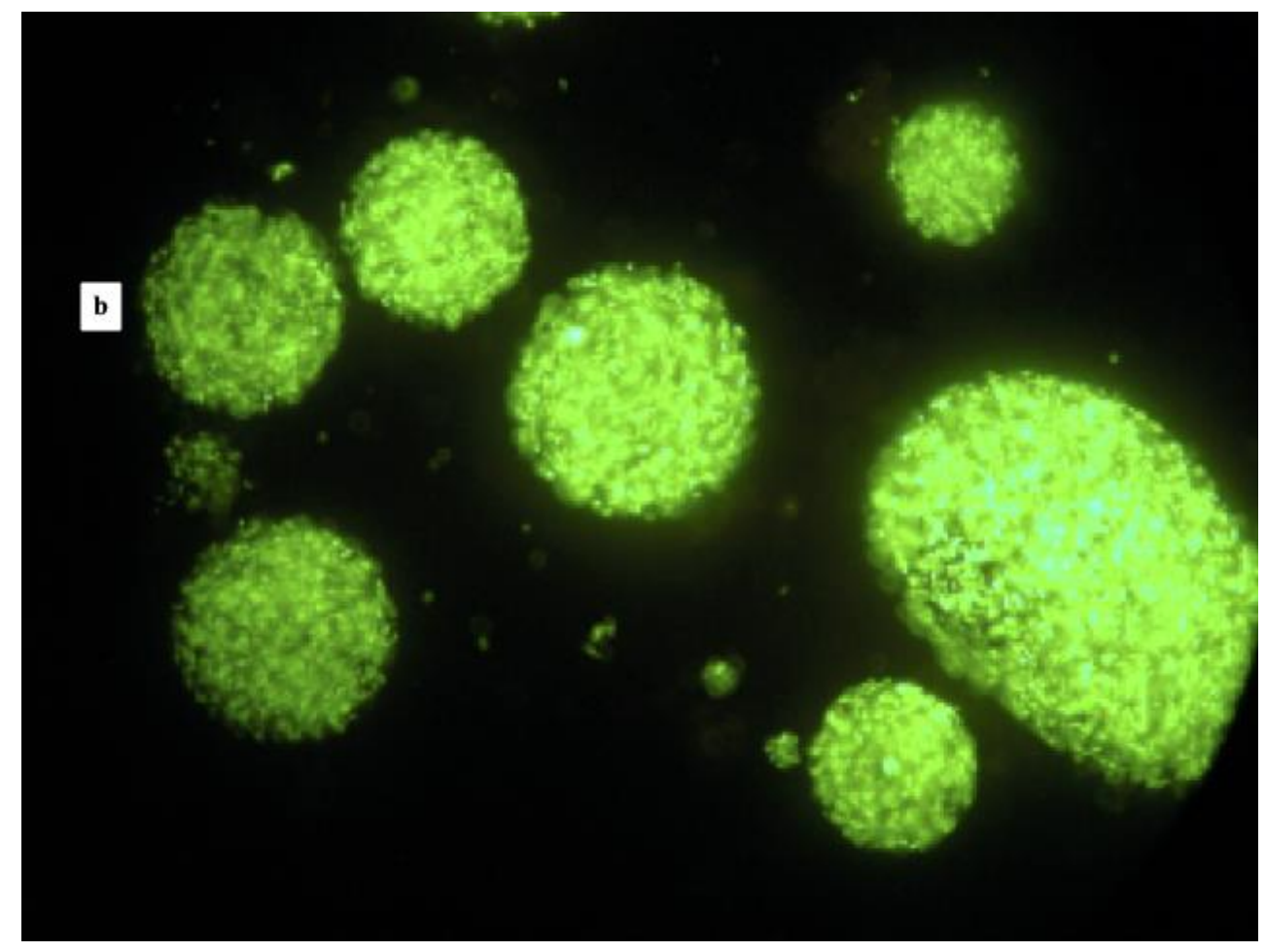

Figure 1. Fluorescence microscopy images at $400 \times$ magnification of microencapsulated cells of L. reuteri DSM 17938 (panel a) and L. plantarum 48M (panel b) after viable staining.

Results regarding the shape and size of microcapsules are in agreement with other studies where microcapsules obtained by emulsion technique were analysed. In particular, Truelstrup Hansen et al. [24] reported that microcapsules loaded with bifidobacteria observed by cryo-scanning electron microscopy were spherically shaped with a smooth or rough surface with a visible outline of entrapped bacteria. Similarly, Khalida Sultana et al. [27] obtained spherical and some elliptical beads with randomly distributed bacteria in the alginate matrix. Finally, Valero-Cases and Frutos [28] obtained by emulsion smaller and more irregularly shaped microcapsules containing L. plantarum CECT 2020, compared to that obtained by the extrusion method.

Each phase obtained after the microencapsulation process was analysed for viable counting, and results are reported in Table 1 . No viable cells were detected in the oily phase, while average values of 7.36 and $4.47 \mathrm{Log} \mathrm{CFU} / \mathrm{mL}$ were registered in water middle phase for L. reuteri DSM 17938 and L. plantarum 48M, respectively. Similar differences between the strains were also detected in the counting of microencapsulated cells. In fact, average values of 9.04 and $7.63 \mathrm{Log} \mathrm{CFU} / \mathrm{mL}$ were registered in the bottom phase for L. reuteri DSM 17938 and L. plantarum 48M, respectively. Consequently, the encapsulation efficiency for L. reuteri DSM 17938 was found to be significantly $(p<0.05)$ higher than L. plantarum $48 \mathrm{M}$.

The microencapsulation efficiency was calculated after adjusting the volumes of the phases by applying the formula previously described (Section 2.4). Specifically, the $\mathrm{CFU} / \mathrm{mL}$ value was adjusted to $100 \mathrm{~mL}$ for both the culture and the aqueous phase: $100 \mathrm{~mL}$ represents the initial volume of the overnight culture to obtain the microbial pellet used for the microencapsulation procedure. Therefore, the microencapsulation yield was $65.28 \%$ for the L. plantarum $48 \mathrm{M}$ and $91.53 \%$ for L. reuteri DSM 17938 (Table 1). In the light of the microencapsulation efficiency results, we can hypothesise that different $\mathrm{CFU} / \mathrm{mL}$ values of obtained phases depend on different compositions of the two strains' bacterial cell membrane, causing diverse interactions with the microencapsulation agents. As a matter of fact, some authors investigated the interaction between bacterial cells and hydrogels, and they found that even the bacterial growth medium can affect this interaction [29]. 


\subsection{Simulated GI Conditions}

The microcapsules exposed to the simulated GI conditions were observed by the fluorescence microscopy. The exposure to simulated gastric conditions did not affect the original microcapsules shape; indeed, as Figure 2a,b shows, the cells of both strains were contained in the microcapsules structure and were all dyed green. In contrast, the exposure in simulated intestinal conditions ruined the capsules structure, causing the cells' discharge. Nevertheless, the cells remained green after $4 \mathrm{~h}$ of exposure (Figure $2 \mathrm{c}, \mathrm{d}$ ).
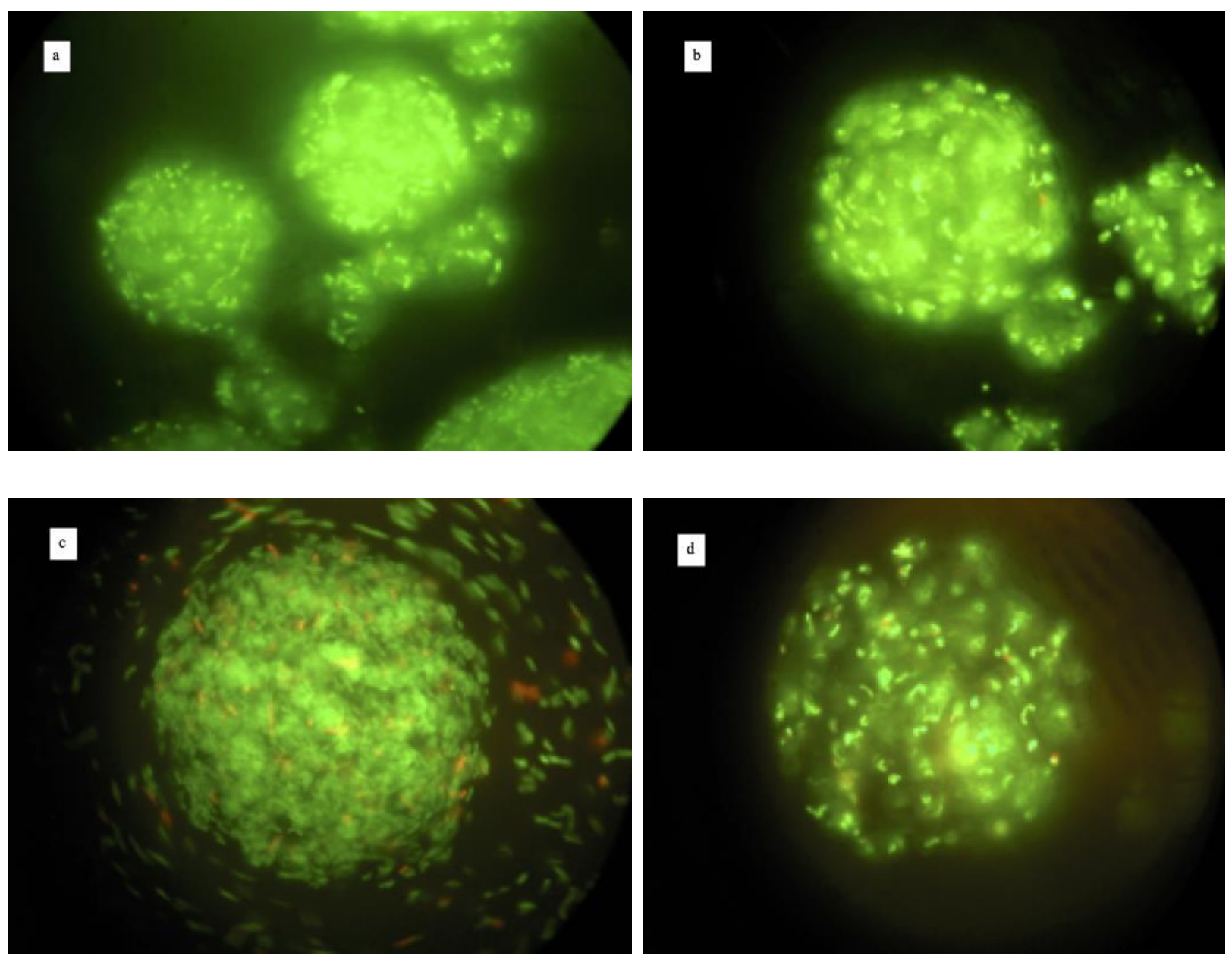

Figure 2. Fluorescence microscopy images at 400× magnification after viable staining of microencapsules of L. reuteri DSM 17938 (panels a,c) and L. plantarum 48M (panels b,d) exposed to gastric (panels a,b) and intestinal (panels c,d) conditions.

The results obtained by counting colonies after the exposure to the simulated GI conditions are shown in the Figure 3.

The abilities of the two bacterial strains to survive the gastric condition were markedly different. In fact, as shown in Figure 3A, the free cells of L. reuteri DSM 17938 showed about $1 \mathrm{Log}$ reduction after $3 \mathrm{~h}$ exposure, compared to the free cells sample of L. plantarum $48 \mathrm{M}$, which reduced viability by about 6 Log cycles (Figure 3B). In detail, the population of 9.16 Log CFU / $\mathrm{mL}$ before exposure remained stable at T0 ( $p>0.05)$, while after $3 \mathrm{~h}$ (T3), the mean value was $8.04(p<0.05)$. On the other hand, the encapsulated cells did not show any significant reduction $(p>0.05)$ after the treatment. Indeed, microcapsules count was 8.17 and $8.76 \mathrm{Log} \mathrm{CFU} / \mathrm{mL}$ before and after $3 \mathrm{~h}$ of exposure, respectively (Figure $3 \mathrm{~A}$ ). As mentioned above, te Figure 3B shows that the strain L. plantarum $48 \mathrm{M}$ is very sensitive to a prolonged exposure to the gastric condition. As a matter of fact, the free cell population remained unchanged immediately after exposure $(p>0.05)$, whereas a dramatic reduction by $5.75 \log$ cycles $(p<0.05)$ of the population occurred after $3 \mathrm{~h}$. On the contrary, 
the encapsulated cells showed better viability once exposed to the gastric condition. In particular, the $\log \mathrm{CFU} / \mathrm{mL}$ of untreated capsules was 7.16 , and no significant $(p>0.05)$ reduction occurred immediately (T0) and after $3 \mathrm{~h}$ (T3) of exposure. Our findings are in agreement with those of other previous works, where microencapsulation in alginate beads was found to increase the survival of probiotics bacteria in gastric conditions $[17,30-35]$. However, to the best of our knowledge, this is the first work in which a non-probiotic microorganism was tested for GI passage resistance in microencapsulated form. Our results clearly demonstrate that there was a slight sensitivity of L. reuteri DSM 17938 in a simulated gastric condition; in fact, it is a bacterial probiotic strain already widely used as an oral supplement. This result confirms what we found in our previous work, in which we tested the same microorganism and the microencapsulation by vibration technology to make it even less sensitive [30]. On the contrary, L. plantarum 48M showed very high susceptibility to the simulated gastric condition, as demonstrated by strong loss of cell viability. Unquestionably, the microencapsulation protected the L. plantarum $48 \mathrm{M}$ cells from the detrimental action of gastric juice components and acidity, as demonstrated by the gap of more than 2 Log cycles between T3 samples of free and encapsulated cells. As is well known, resistance to GI conditions is pivotal in the selection of new probiotic microorganisms, making many potential probiotic microorganisms be discarded for their susceptibility to GI transit. Thus, microencapsulation could enhance the number of potential probiotics for food supplementation purposes.
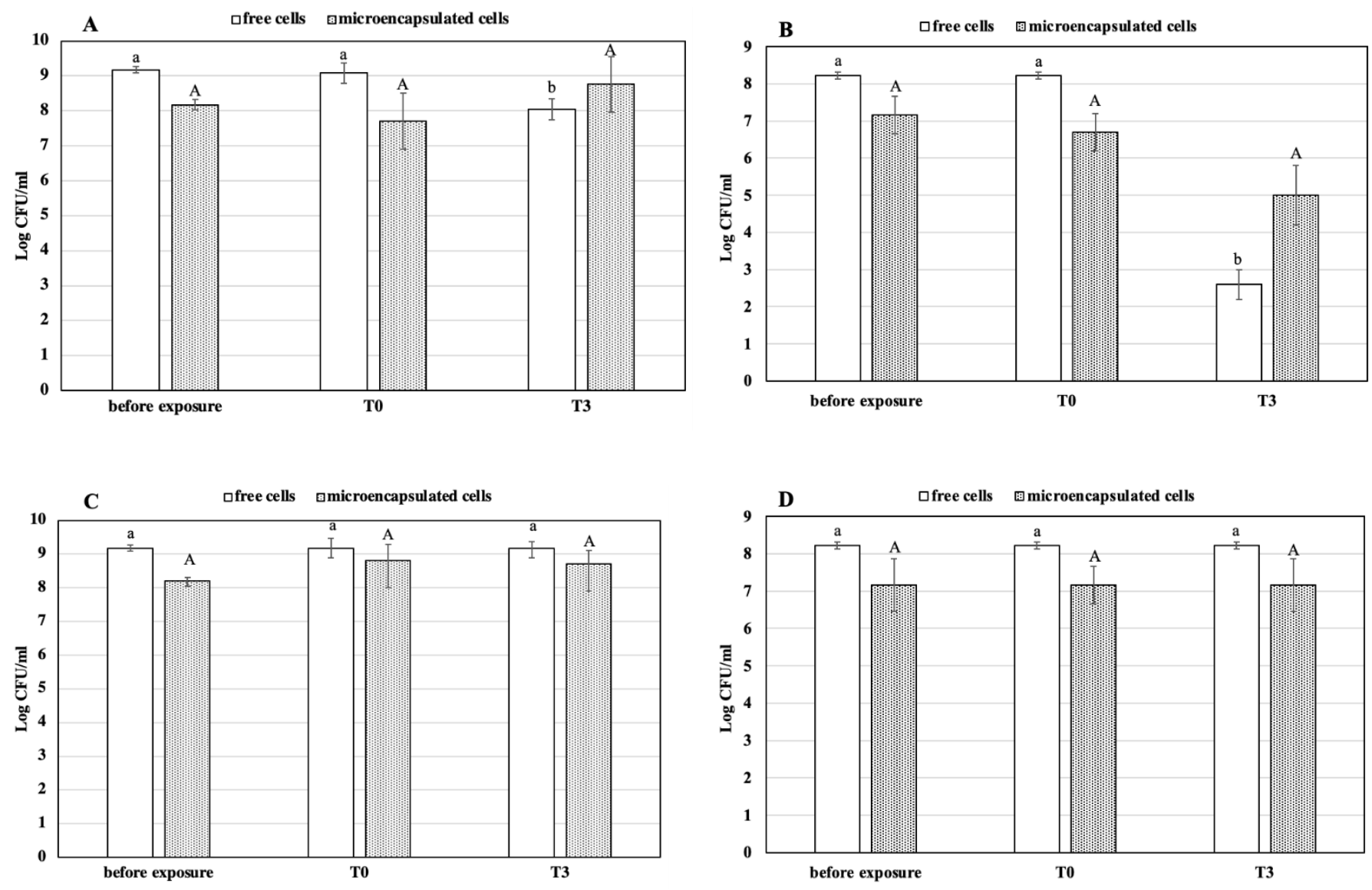

Figure 3. Cell survival of free and microencapsulated cells of L. reuteri DSM 17938 (panels A,C) and L. plantarum 48M (panels B,D) after simulated gastric (panels A,B) and intestinal (panels C,D) conditions. Values are means of three independent experiments + / - SD. Different letters (lower for free and capital for encapsulated cells) on the bars indicate significant difference $(p \leq 0.05)$ of the mean values between sample before exposure and samples T0 and T3, as a result of $t$-test.

The protective effect also depends on the beads' size: Lee and Heo [33] reported that the survival of encapsulated cells decreased with decreasing of beads size. Moreover, 
the concentration of sodium alginate may also affect the survival of cells under acidic conditions, as $1.8 \%$ sodium alginate was the optimal concentration among those tested.

The results obtained after exposure to the intestinal conditions did not show any reduction of survival in both strains. An increase in cell load even occurred at the end of incubation period. The number of free cells of L. reuteri DSM 17938 showed no significant changes under the same simulated conditions. On the contrary, the encapsulated cells were increased by $0.69 \mathrm{Log} \mathrm{CFU} / \mathrm{mL}$ at T0 $(p<0.05)$ and remained stable for the whole exposure time (Figure 3C). Similarly, the presence of $0.3 \%$ of bile had no lethal effect on the free and encapsulated cells of L. plantarum $48 \mathrm{M}$; indeed, the count of the cells in both conditions remained steady after $4 \mathrm{~h}$ of exposure (Figure 3D).

The two strains, both free and encapsulated, appeared to be resistant to the intestinal simulated conditions. On the other hand, Muthukumarasamy et al. [36] reported that five strains of $L$. reuteri can survive in presence of $1.2 \%$ bile for $6 \mathrm{~h}$. The increased number of CFU/mL of microencapsulated L. reuteri DSM 17938 cells under simulated intestinal conditions could be due to the bile salt action. Accordingly, Smidsrod and Skijak-brack [37] demonstrated that the alginate gel is subjected to deterioration when in contact with the monovalent ions, which sequester the calcium ions, causing the cells to be released from the microcapsules. An advantage of this behaviour is that released cells are able to colonise the intestine.

\subsection{Heat Treatment of Free and Microencapsulated Cells}

The heat resistance was assessed by exposing free and microencapsulated cells to four time-temperature combinations. The images captured by the fluorescence microscopy show that both bacterial strains had different sensitivity once exposed to high temperature (Figure 4). According to the images, the structure of microcapsules containing L. reuteri DSM 17938 (Figure 4a,c,e,g) was not affected by the heat, even though the treatment at $80^{\circ} \mathrm{C}$ for $5 \mathrm{~min}$ caused the microcapsules damage, with some free cells releasing. At the same time, the cells contained in the microcapsules appeared all dyed green; consequently, no cell membrane damage occurred at any tested temperatures. It is noteworthy that free cells appeared dyed red after treatment at $60^{\circ} \mathrm{C}$ for 3 min already (data not shown). Despite the integrity of microencapsulated cells' membranes, a low survival rate was found after exposing free and microencapsulated cells of L. reuteri DSM 17938 to the heat treatments (Table 2). Indeed, at $60{ }^{\circ} \mathrm{C}$, the free cells survival rate was $1.02 \%$ and $0.89 \%$ for the microencapsulated ones. When the temperature increased by $10^{\circ} \mathrm{C}$, the survival rate was further reduced; in fact, it was $0.0021 \%$ for microencapsulated and $0.0042 \%$ for the free cells. Finally, no heat resistance was found treating the samples at $80^{\circ} \mathrm{C}$, both for 2 and $5 \mathrm{~min}$; indeed only a few cells survived.
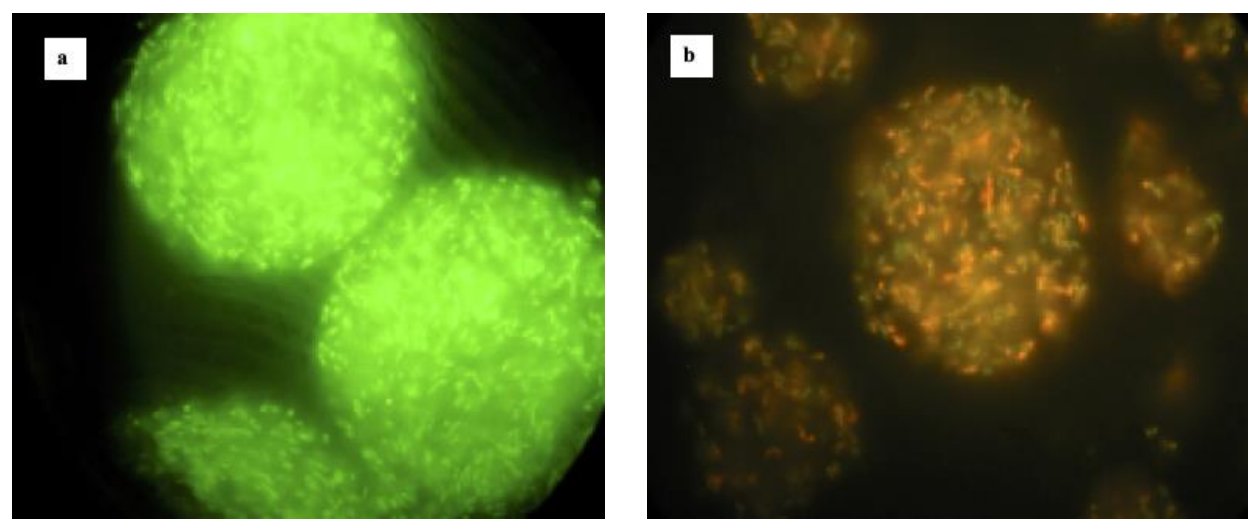

$65^{\circ} \mathrm{C} \times 3 \mathrm{~min}$

Figure 4. Cont . 

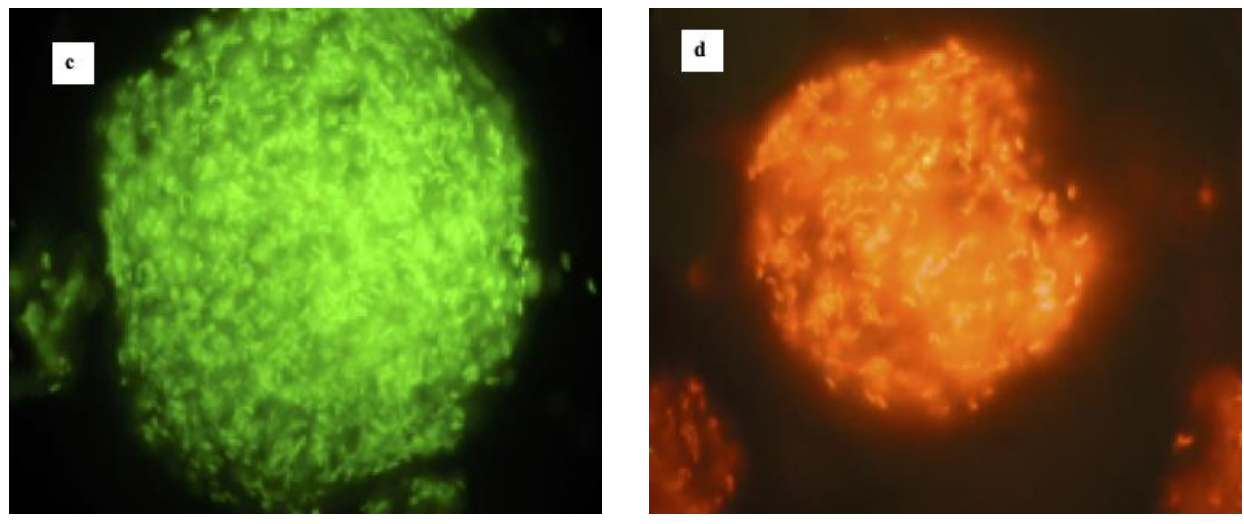

$70^{\circ} \mathrm{C} \times 2 \mathrm{~min}$
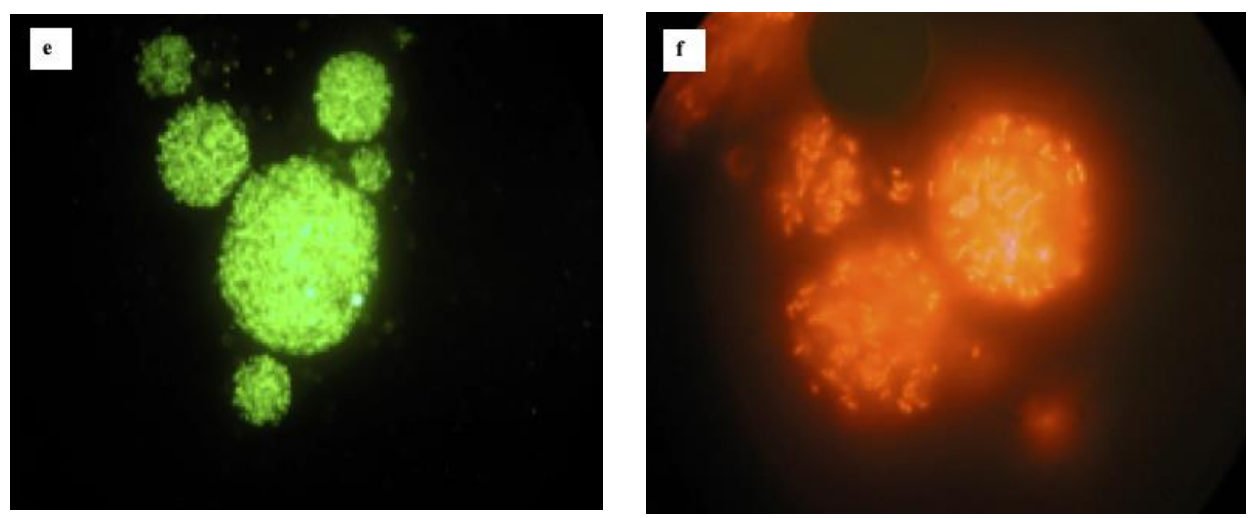

$70^{\circ} \mathrm{C} \times 2 \mathrm{~min}$
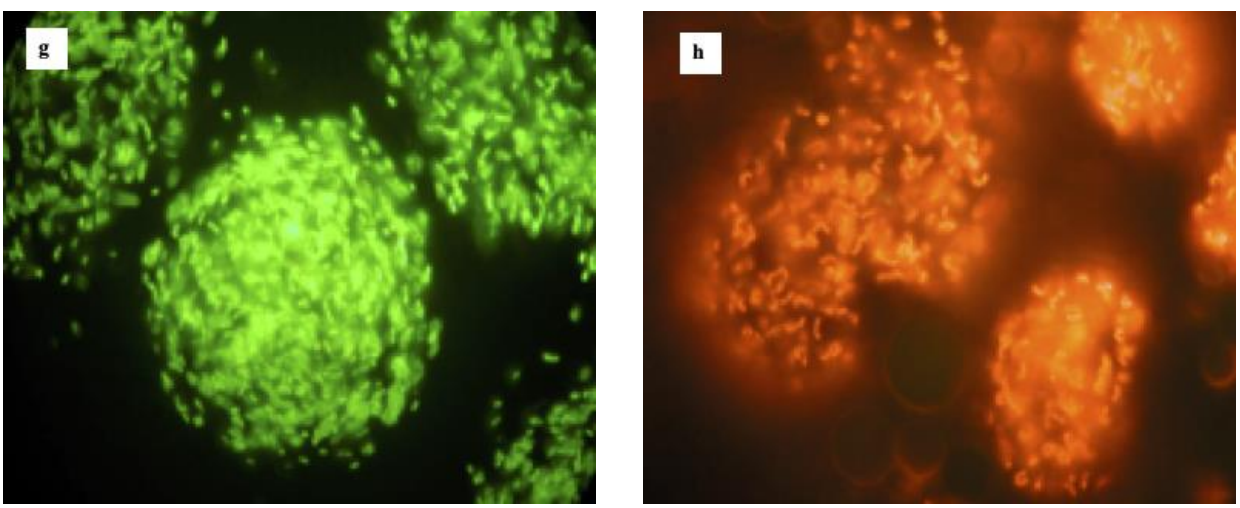

$80^{\circ} \mathrm{C} \times 5 \mathrm{~min}$

Figure 4. Viable staining of microencapsulated cells of L. reuteri DSM 17938 (panels a,c,e,g) and L. plantarum 48M (b,d,f,h) after different heat treatments as indicated on the right sides of panels.

Table 2. Survival rate (\%) of free and microencapsulated cells of L. reuteri DSM17938 and L. plantarum 48M after different heat treatments.

\begin{tabular}{ccccccccc}
\hline \multirow{2}{*}{ Sample } & \multicolumn{4}{c}{ L. reuteri DSM 17938 } & \multicolumn{3}{c}{ L. plantarum 48M } \\
\cline { 2 - 8 } & $\mathbf{6 0}{ }^{\circ} \mathbf{C} \times \mathbf{3}^{\prime}$ & $\mathbf{7 0}^{\circ} \mathbf{C} \times \mathbf{2}^{\prime}$ & $\mathbf{8 0} \mathbf{C} \times \mathbf{2}^{\prime}$ & $\mathbf{8 0}{ }^{\circ} \mathbf{C} \times \mathbf{5}^{\prime}$ & $\mathbf{6 0}^{\circ} \mathbf{C} \times \mathbf{3}^{\prime}$ & $\mathbf{7 0}^{\circ} \mathbf{C} \times \mathbf{2}^{\prime}$ & $\mathbf{8 0}^{\circ} \mathbf{C} \times \mathbf{2}^{\prime}$ & $\mathbf{8 0}^{\circ} \mathbf{C} \times \mathbf{5}^{\prime}$ \\
\hline $\begin{array}{c}\text { free cells } \\
\text { microencapsulated } \\
\text { cells }\end{array}$ & 1.02 & $4.2 \times 10^{-3}$ & 0.0011 & $1.9 \times 10^{-6}$ & 0.0039 & $3.5 \times 10^{-4}$ & $7.8 \times 10^{-5}$ & $3.0 \times 10^{-5}$ \\
\hline
\end{tabular}

The observation from the fluorescence microscopy also showed no damage to the structure of microcapsules containing L. plantarum 48M, and they kept their spherical shape during all treatments (Figure $4 \mathrm{~b}, \mathrm{~d}, \mathrm{f}, \mathrm{h}$ ). The main difference from the L. reuteri DSM 17938 was the membrane damage after viable staining. Indeed, the cells appeared all dyed red, 
except for the treatment at $60{ }^{\circ} \mathrm{C}$ for $3 \mathrm{~min}$, where some green cells were also detected. Moreover, as shown in Figure 4, as the temperature increased, the red colour became more intensive. This means that the high temperatures damaged the cell membrane of L. plantarum 48M. In this case, we could expect a low survival rate considering the colour of the cells after viable staining. In fact, the high temperature dramatically reduced the population load of either free or microencapsulated L. plantarum $48 \mathrm{M}$ cells. Specifically, the survival rate of L. plantarum $48 \mathrm{M}$ at $60{ }^{\circ} \mathrm{C}$ was $0.0039 \%$ for free and $0.0008 \%$ for microencapsulated cells. Furthermore, higher temperatures $\left(70{ }^{\circ} \mathrm{C}\right.$ and $\left.80^{\circ} \mathrm{C}\right)$ were lethal for the microencapsulated cells, whereas only few free cells survived these treatments (Table 2).

Although it has been well established that the LIVE/DEAD ${ }^{\circledR}$ Bacterial Viability Kit $\left(B a c\right.$ Light $\left.^{\mathrm{TM}}\right)$ enables differentiation only between bacteria with intact and damaged cytoplasmic membranes, it is often used to differentiate between active and dead cells [38,39]. While it seems accurate to assume that membrane-compromised bacterial cells can be considered dead [40,41], the reverse (intact membranes means active cells) is not necessarily true [42]. Our results seem to confirm these findings; indeed, the cells of L. plantarum 48M were found all dyed red, and the results of viable plate count show that there was high mortality after exposure to the heat treatments. Differently, the cells of L. reuteri DSM 17938 appeared dyed green even though the plate viable count detected a high mortality. Confirming our results, many authors demonstrated that bacterial cells staining with SYTO9 and Propidium Iodide do not always produce distinct "live" and "dead" populations [40,42-46]. In light of our findings, we can hypothesise a different composition of cytoplasmic membrane of two microorganisms tested, which determined the different behaviour when exposed to the heat treatments.

The results of the present study show that the microencapsulation does not improve the survival of cells once subjected to heat treatments. In particular, the microencapsulated cells of L. plantarum $48 \mathrm{M}$ were more sensitive than the free ones. After the treatments at $60^{\circ} \mathrm{C}$ for $3 \mathrm{~min}$ and $70^{\circ} \mathrm{C}$ for $2 \mathrm{~min}$, the free cells survived better than the microencapsulated ones $(p<0.05)$. In addition, there was no microencapsulated cell survival $(p>0.05)$ for the treatments at $80^{\circ} \mathrm{C}$ for 2 and $5 \mathrm{~min}$. On the other hand, no significant difference was found between the free and microencapsulated cells for all the treatments executed. Accordingly, previous studies show that microencapsulation does not improve bacteria survival after exposure to the heat treatment. Malmo et al. [25] reported that microencapsulation of L. reuteri DSM 17938 by spray drying did not improve the heat tolerance when samples were treated at the same time-temperature combinations used in the present study.

The heat tolerance results are dependent on several factors: strain, temperature, microcapsules size, concentration of sodium alginate, etc. In fact, some studies carried out by other authors demonstrated that microencapsulation can improve the cells survival at certain temperatures. Mandal et al. [34] reported that the survival of Lactobacillus casei NCDC-298 was improved by the microencapsulation using $4 \%(w / v)$ of sodium alginate; moreover, the temperature was not higher than $65^{\circ} \mathrm{C}$. The improvement of survival was due to the low diffusion of water into the alginate matrix of microcapsules. Similarly, Ding and Shah [47] demonstrated that a lower concentration of sodium alginate $(3 \% w / v)$ also improved the survival of lactobacilli treated at $65^{\circ} \mathrm{C}$.

\subsection{Reuterin Production Assay}

The assessment of reuterin production by microencapsulated cells of L. reuteri DSM 17938 was evaluated by performing an antagonist assay using three indicator strains (Escherichia coli 32, Hafnia alvei 53M and Pseudomonas fragi 25P). The microcapsules used to perform the assay were freshly made or kept at $4{ }^{\circ} \mathrm{C}$ for 1 week and 4 months. The results showed that $L$. reuteri DSM 17938 kept the ability to produce the antimicrobial agent even after microencapsulation. Moreover, microencapsulated cells produced a clear inhibition zone (Figure 5) also four months after microencapsulation (data not shown). Our results are in agreement with the findings of Malmo et al. [25], who demonstrated 
that microencapsulated L. reuteri DSM 17938 was able to produce reuterin active against Pseudomonas fragi 25P.

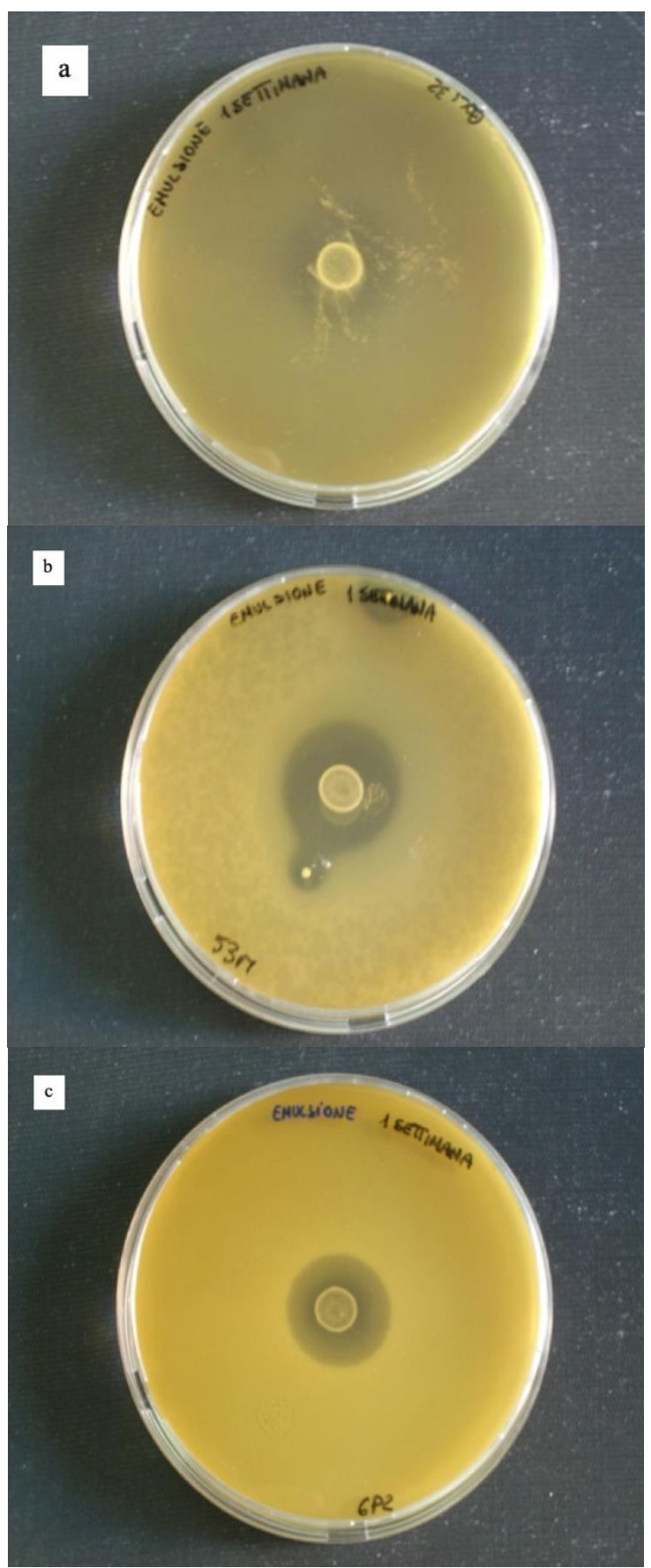

Figure 5. Antimicrobial activity of 1 week old L. reuteri DSM 17938 microencapsules against E. coli 32 (panel a), H. alvei 53M (panel b) and P. fragi 6P2 (panel c).

\section{Conclusions}

The findings of the present study revealed that microencapsulation by emulsion exerts a protective effect on bacterial cells when exposed to GI conditions. In particular, even cells of a non-probiotic strain after microencapsulation by emulsion reached survival levels of a well known probiotic strain. Unfortunately, probiotic and non-probiotic microencapsulated cells did not have a higher percentage of survival when subjected to heat stress compared to free cells. 
Author Contributions: Conceptualization, G.M. and C.M.; methodology, G.M.; data analysis, C.M. and I.G.; investigation, G.M., C.M. and I.G.; data curation, G.M.; writing-original draft preparation, C.M.; writing-review and editing, G.M.; supervision, G.M. All authors have read and agreed to the published version of the manuscript.

Funding: This research did not receive any specific grant from funding agencies in the public, commercial, or not-for-profit sector.

Data Availability Statement: Not applicable.

Conflicts of Interest: The authors declare no conflict of interest.

\section{References}

1. Korhonen, H. Technology options for new nutritional concepts. Int. J. Dairy Technol. 2002, 55, 79-88. [CrossRef]

2. Vasiljevic, T.; Shah, N.P. Probiotics-from Metchnikoff to bioactives. Int. Dairy J. 2008, 18, 714-728. [CrossRef]

3. Wiseman, A.; Woods, L. Addition of designer enhancers to functional foods: Need also for redesigned biocatalysts in fail-clean strategies of bioprocessing? J. Chem. Technol. Biol. 2001, 76, 1038-1040. [CrossRef]

4. Tur, J.A.; Bibiloni, M.M. Functional foods. Reference module in food science. In Encyclopedia of Food and Health; Elsevier: Kidlington, UK, 2016.

5. Heller, K.J. Probiotic bacteria in fermented foods: Product characteristics and starter organisms. Am. J. Clin. Nutr. 2001, 72, 374S-379S. [CrossRef] [PubMed]

6. Stanton, C.; Gardiner, G.; Meehan, H.; Collins, K.; Fitzgerald, G.; Lynch, P.B.; Ross, R.P. Market potential for probiotics. Am. J. Clin. Nutr. 2001, 73, 476S-483S. [CrossRef]

7. Hill, C.; Guarner, F.; Reid, G.; Gibson, G.R.; Merenstein, D.J.; Pot, B.; Morelli, L.; Canani, R.B.; Flint, H.J.; Salminen, S.; et al. The International Scientific Association for Probiotics and Prebiotics consensus statement on the scope and appropriate use of the term probiotic. Nat. Rev. Gastroenterol. Hepatol. 2014, 11, 506-514. [CrossRef]

8. FAO/WHO. Report of a Joint FAO/WHO Expert Consultation on Evaluation of Health and Nutritional Properties of Probiotics in Food Including Powder Milk With Live Lactic Acid Bacteria; FAO: Rome, Italy, 2001.

9. Zheng, J.; Wittouck, S.; Salvetti, E.; Franz, C.M.A.P.; Harris, H.M.B.; Mattarelli, P.; O’Toole, P.W.; Pot, B.; Vandamme, P.; Walter, J.; et al. A taxonomic note on the genus Lactobacillus: Description of 23 novel genera, emended description of the genus Lactobacillus Beijerinck 1901, and union of Lactobacillaceae and Leuconostocaceae. Int. J. Syst. Evol. Microbiol. 2020, 70, 2782-2858. [CrossRef]

10. Figueroa-Gonzales, I.; Quijano, G.; Ramirez, G.; Cruz-Guerrero, A. Probiotics and prebiotics- perspectives and challenges. J. Sci. Food Agric. 2011, 91, 1341-1348. [CrossRef]

11. Tripathi, M.K.; Giri, S.K. Probiotic functional foods: Survival of probiotics during processing and storage. J. Funct. Foods 2014, 9 , 225-241. [CrossRef]

12. Yao, M.; Xie, J.; Du, H.; McClements, D.J.; Xiao, H.; Li, L. Progress in microencapsulation of probiotics: A review. Compr. Rev. Food Sci. Food Saf. 2020, 19, 857-874. [CrossRef]

13. Anal, A.K.; Stevens, W.F. Chitosan-alginate multilayer beads for controlled release of ampicillin. Int. J. Pharm. 2005, 290, 45-54. [CrossRef] [PubMed]

14. Anal, A.K.; Singh, H. Recent advances in microencapsulation of probiotics for industrial applications and targeted delivery. Trends Food Sci. Techol. 2007, 18, 240-251. [CrossRef]

15. De Vos, P.; Faas, M.M.; Spasojevic, M.; Sikkema, J. Encapsulation for preservation of functionality and targeted delivery of bioactive food components. Int. Dairy J. 2010, 20, 292-302. [CrossRef]

16. Song, H.; Yu, W.; Gao, M.; Liu, X.; Ma, X. Microencapsulated probiotics using emulsification technique coupledwith internal or external gelation process. Carbohydr. Polym. 2013, 96, 181-189. [CrossRef] [PubMed]

17. Krasaekoopt, W.; Bhandari, B.; Deeth, H. Evaluation of encapsulation techniques of probiotics for yoghurt. Int. Dairy J. 2003, 13, 3-13. [CrossRef]

18. Mu, Q.; Tavella, V.J.; Luo, X.M. Role of Lactobacillus reuteri in human health and diseases. Front. Microbiol. 2018, 9, 757. [CrossRef]

19. Cleusix, V.; Lacroix, C.; Vollenweider, S.; Le Blay, G. Glycerol induces reuterin production and decreases Escherichia coli population in an in vitro model of colonic fermentation with immobilized human feces. FEMS Microbiol. Ecol. 2008, 63, 56-64. [CrossRef]

20. Talarico, T.L.; Casas, I.A.; Chung, T.C.; Dobrogosz, W.J. Production and isolation of reuterin: A growth inhibitor produced by Lactobacillus reuteri. Antimicrob. Agents Chemother. 1988, 32, 1854-1858. [CrossRef]

21. Liu, Y.W.; Liong, M.T.; Tsai, Y.C. New perspectives of Lactobacillus plantarum as a probiotic: The gut-heart-brain axis. J. Microbiol. 2018, 56, 601-613. [CrossRef]

22. Ercolini, D.; Russo, F.; Nasi, A.; Ferranti, P.; Villani, F. Mesophilic and psychotropic bacteria from meat and their spoilage potential in vitro and in beef. Appl. Environ. Microb. 2009, 75, 1990-2001. [CrossRef]

23. Sheu, T.Y.; Mashall, R.T. Microentrapment of lactobacilli in calcium alginate gels. J. Food Sci. 1993, 54, 557-561. [CrossRef]

24. Truelstrup Hansen, L.; Allan-Wojtas, P.M.; Jin, Y.L.; Paulson, A.T. Survival of Ca-alginate microencapsulated Bifidobacterium spp. in milk and simulated gastrointestinal conditions. Food Microbiol. 2002, 19, 35-45. [CrossRef] 
25. Malmo, C.; La Storia, A.; Mauriello, G. Microencapsulation of Lactobacillus reuteri DSM 17938 cells coated in alginate beads with chitosan by spray drying to use as a probiotic cell in a chocolate soufflé. Food Bioprocess. Technol. 2013, 6, 795-805. [CrossRef]

26. Villani, F.; Salzano, G.; Sorrentino, E.; Pepe, O.; Marino, P.; Coppola, S. Enterocin 226 NWC, a bacteriocin produced by Enterococcus faecalis 226 active against Listeria monocytogenes. J. Appl. Bacteriol. 1993, 74, 380-387. [CrossRef] [PubMed]

27. Sultana, K.; Godward, G.; Reynolds, N.; Arumugaswamy, R.; Peiris, P.; Kailasapathy, K. Encapsulation of probiotic bacteria with alginate-starch and evaluation of survival in simulated gastrointestinal conditions and in yoghurt. Int. J. Food Microbiol. 2000, 62, 47-55. [CrossRef]

28. Valero-Cases, E.; Frutos, M.J. Effect of different types of encapsulation on the survival of Lactobacillus plantarum during storage with inulin and in vitro digestion. LWT Food Sci. Technol. 2014, 64, 824-828. [CrossRef]

29. Kandemir, N.; Vollmer, W.; Jakubovics, N.S.; Chen, J. Mechanical interactions between bacteria and hydrogels. Sci. Rep. 2018, 8, 10893. [CrossRef]

30. De Prisco, A.; Maresca, D.; Ongeng, D.; Mauriello, G. Microencapsulation by vibrating technology of the probiotic strain Lactobaciluus reuteri DSM 17938 to enhance its survival in foods and in gastrointestinal environment. LWT Food Sci. Technol. 2015, 61, 452-462. [CrossRef]

31. De Prisco, A.; von Valenberg, H.J.F.; Fogliano, V.; Mauriello, G. Microencapsulated starter culture during yoghurt manufacturing, effect on technological features. Food. Bioprocess. Technol. 2017, 10, 1767-1777. [CrossRef]

32. Iyer, C.; Kailasapathy, K. Effect of co-encapsulation of probiotics with prebiotics on increasing the viability of encapsulated bacteria under in vitro acidic and bile salt conditions and in yogurt. J. Food Sci. 2005, 70, 18-23.

33. Lee, K.Y.; Heo, T.R. Survival of Bifidobacterium longum immobilized in calcium alginate beads in simulated gastric juices and bile salt solution. Appl. Environ. Microbiol. 2000, 66, 869-873. [CrossRef] [PubMed]

34. Mandal, S.; Puniya, A.K.; Singh, K. Effect of alginate concentrations on survival of microencapsulated Lactobacillus casei NCDC-298. Int. Dairy J. 2006, 16, 1190-1195. [CrossRef]

35. Sathyabama, S.; Ranjith, K.M.; Devi, P.B.; Vijayabharathi, R.; Priyadharisini, V.B. Co-encapsulation of probiotics with prebiotics on alginate matrix and its effect on viability in simulated gastric environment. Food Sci. Technol. 2014, 57, 419-425. [CrossRef]

36. Muthukumarasamy, P.; Allan-Wojtas, P.; Holley, R.A. Stability of Lactobacillus reuteri in different type of microcapsules. J. Food Sci. 2006, 71, 20-24. [CrossRef]

37. Smidsrod, O.; Skijak-Brack, G. Alginate as immobilization matrix for cells. Trends Biotechnol. 1990, 8, 71-78. [CrossRef]

38. Gasol, J.M.; Zweifel, U.L.; Peters, F.; Fuhrman, J.A.; Hagstrom, A. Significance of size and nucleic acid content heterogeneity as measured by flow cytometry in natural planktonic bacteria. Appl. Environ. Microbiol. 1999, 65, 4475-4483. [CrossRef]

39. Sachidanandham, R.; Gin, K.Y.; Poh, C.L. Monitoring of active but non-culturable bacterial cells by flow cytometry. Biotechnol. Bioeng. 2005, 89, 24-31. [CrossRef]

40. Berney, M.; Weilenmann, H.U.; Egli, T. Flow-cytometric study of vital cellular functions in Escherichia coli during solar disinfection (SODIS). Microbiology 2006, 152, 1719-1729. [CrossRef]

41. Nebe-von-Caron, G.; Stephens, P.J.; Hewitt, C.J.; Powell, J.R.; Badley, R.A. Analysis of bacterial function by multi-colour fluorescence flow cytometry and single cell sorting. J. Microbiol. Meth. 2000, 42, 97-114. [CrossRef]

42. Joux, F.; Lebaron, P. Use of fluorescent probes to assess physiological functions of bacteria at single-cell level. Microbes Infect. 2000, 2, 1523-1535. [CrossRef]

43. Barbesti, S.; Citterio, S.; Labra, M.; Baroni, M.D.; Neri, M.G.; Sgorbati, S. Two- and three-color fluorescence flow cytometric analysis of immunoidentified viable bacteria. Cytometry 2000, 40, 214-218. [CrossRef]

44. Christiansen, T.; Michaelsen, S.; Wumpelmann, M.; Nielsen, J. Production of savinase and population viability of Bacillus clausii during high-cell-density fed-batch cultivations. Biotechnol. Bioeng. 2003, 83, 344-352. [CrossRef] [PubMed]

45. Hoefel, D.; Grooby, W.L.; Monis, P.T.; Andrews, S.; Saint, C.P. Enumeration of water-borne bacteria using viability assays and flow cytometry: A comparison to culture-based techniques. J. Microbiol. Meth. 2003, 55, 585-597. [CrossRef]

46. Virta, M.; Lineri, S.; Kankaanpaa, P.; Karp, M.; Peltonen, K.; Nuutila, J.; Lilius, E.M. Determination of complement-mediated killing of bacteria by viability staining and bioluminescence. Appl. Environ. Microbiol. 1998, 64, 515-519. [CrossRef]

47. Ding, W.K.; Shah, N.P. Acid, bile, and heat tolerance of free and microencapsulated probiotic bacteria. J. Food Sci. 2007, 72, M446-M450. [CrossRef] 